\title{
Dynamics of career development of Giriloyo batik makers
}

\author{
Nur Hasanab \\ ${ }^{1}$ Department of Psychology, Universitas Negeri Yogyakarta \\ Jl. Colombo No. 1 Karang Malang, Sleman, Yogyakarta ${ }^{1}$ \\ nur.hasanah2015@student.uny.ac.id
}

\begin{abstract}
The purpose of this study is to describe the dynamics of the career development on each stage, starting from growth, exploration and establishment in Batik makers of Giriloyo. This study employs case study qualitative research methods, and involves three women who worked as batik maker. Data analysis was performed by data reduction, data presentation, and conclusion drawing. From this research it is revealed that participants did not fulfill the developmental tasks at all three stages as a whole and they went through stages of career development sequences and period that is differed from the established theory of career development. It is also revealed that the participants experienced dissatisfaction with the wages. However, in the other hand they felt proud to be able to take part on their community and wishes to continue to make batik as long as they are physically able. The results of the study led researchers to recommend early career recognition by families, schools and communities.
\end{abstract}

Keywords: career development; career development tasks, batik

\section{Introduction}

The field of work orientation experiences a lot of changes as the world changes. Although evolution is slow, largescale factors that operate at the macro level, such as industrialization, modernization, colonization, westernization, and globalization, ultimately force humans to adapt to changing job demands. Changes in the work structure driven by globalization, technological developments and the communication revolution forced workers to make major adjustments (Burke and $\mathrm{Ng}$, 2006, in Gross-Spector and Cinamon, 2016).

In line with the changes that occur, new problems arise in the form of human adaptation to work (Arulmani, Bakshi, Leong, et al, 2014). Behavioral scientists then emerged to tackle increasingly complex work problems. One such scientist is Donald Super who explained that his career begins with one point and ends at another point, that can be divided into five stages. The first one is stage of growth (4-13 years); followed by exploration stage (14-24 years); establishment stage (25-44 years); maintenance stage (45-65 years); and lastly, disengagement stage (over 65 years) (Brown \& Lent, 2015). Within each of these stages one's are expected to fulfill developmental tasks in order to have a foundation to move forward to the next stage and reduce the risk of experiencing difficulties in the next stage (Super, 1996 in Brown \& Lent, 2015).

The growth stage has the main goal of forming a realistic vocational self-concept, which in part was formed from the process of identification with their significant others (Brown \& Lent, 2013). Super (1976) explained that the growth stage is the stage of interaction between the self, home, and school environment that influences the development of abilities, interests, and values. Hartung, Porfeli, and Vondracek (2005) supports this notion and added parents have a significant influence at this stage. Savickas and Super (1993 in Brown \& Lent, 2013) convey the task of career development at this stage as 
concern for the future (concern), have control over decision making (control), confidence to achieve goals (conviction), and build competence in work attitudes and work habits (competence). Children must learn to imagine, be responsible, and be able to solve problems in order to be able to build a future image of work that is decent and consistent with the cultural values channeled by the family and the environment.

The exploration phase is dominated by conscious activities seeking information about themselves and the job market. There are two aspects of exploration, namely selfexploration and environmental exploration (Stumpf, Colarelli, \& Hartman, 1983 in Guan, Liu, Guo, Li, Wu, Chen, Xu, \& Tian, 2018). Self-exploration is a way of exploration by looking at their internal attributes to understand who they are, whereas, environmental exploration is the search for information on jobs, organizations, and occupations. Super (1972) explained that bad career exploration is not systematic, whereas, good exploration will further develop the abilities and interests of individuals. These good explorations will clarify the suitability of the role of the role model in the growth stage which has formed its initial self-concept with individual career preferences after exploration. This exploration stage has developmental task of crystallization, specification (specifying), and implementation (Brown \& Lent: 2013). Crystallization means building clear and stable vocational selfconcepts based on occupational preferences and individual ability levels. Vocational education specifications and choices are in line with vocational self-concepts resulting from broad exploration related to work preferences and building a vocational identity. After being specified, implementing career choices requires preparation to occupy a position and obtain that position.

The establishment stage involves the development of a stable self-concept and career pattern originating from the success in career formation where the main goal is to implement the concept of self in the work role so as to produce a meaningful source of income and work life. Work that is filled with meaning, requires individuals to understand their self-concepts in other areas of life, such as roles as parents, husband or wife, and part of the community (Brown and Lent, 2013). The first developmental task in this stage is stabilizing, including settling and securing a position in a job by working competently and adjusting well in the work culture at the job. This then provides a way for consolidating positions through ongoing work productivity, interpersonal effectiveness, and adjustments, so that individuals are able to pursue advancing to a higher position if possible.

Tiedeman, Roe, Super, \& Holland (1972) explained that the most important stage, along the continuation of career development, was the stage of exploration and establishment. According to Super (1980) this stage is the most important, because in the exploration stage, individuals are directly involved, tentatively, transitioned, and try a job with a small commitment, then, an experiment with more commitments, carried out at the establishment stage which includes stabilizing and advancing. The task of his career development then becomes: crystallizing vocational preferences, carrying out specifications, implementing them, stabilizing positions in selected jobs, consolidating self-status, and making selfpromotion efforts at the job.

Even though the work orientation changed a lot, however, batik makers in Giriloyo Hamlet, Wukirsari, Imogiri, Bantul, D. I. Yogyakarta continues to preserve the work of their ancestors. Batik from Giriloyo has special features because its motifs are a legacy of the Yogyakarta Sultanate introduced to the Giriloyo makers around 17th century. Batik Makers in this study are whom involved in one of the stages in the batik making process, namely carving wax onto the cloth using canthing. before or in-between several coloring processes. Generally, batik making and wax carving activities are carried out by women, while the coloring process is carried out by men.

Results from the preliminary study revealed that parents have directed the careers of their daughters from an early age, in this sense the daughter are a passive party and 
does not contribute much in the decision making. In Giriloyo, elementary school age children are able to make batik well. However, it limits their freedom to choose a career because the environment primed them to work as batik makers. In addition, there are gender stereotypes that also limits their career aspiration, mainly villager's expectation for women to take care of the household and children. Based on career development stage, exploration stage was not passed by batik makers who have been in the establishment stage since they are 12 years old, which they should be at the growth stage.

Conditions that occur in communities that work as batik makers are special conditions, especially when viewed from the perspective of career development theory. This makes the gap between reality in the case of batik makers in Giriloyo with career development theory. In addition, the freedom to choose a career and self-actualization of women in Giriloyo is also limited by gender stereotypes, values, norms and traditions held by the community. Therefore, it is important to understand these unique case of career development, especially in growth, exploration, and establishment stages in batik makers of Giriloyo.

\section{Methods}

\section{Research Design}

This research uses a qualitative approach with a case study method directed to understand the unique career development pattern of Giriloyo batik makers.

\section{Research Participants}

Inclusion criteria for this study are: 1) Women between the ages of $25-44 ; 2$ ) Currently working as batik maker; 3) Has been making batik since the age of 12 . The first criteria were based on the theoretical basis that states individual aged 25 to 44 typically have already entered the establishment stage. Whereas the third criteria were based on the result of pre-eliminary study that revealed 12 years old as average starting age for batik makers in Giriloyo. Based on the discussion with Giriloyo village chief, three participants fulfill the inclusion criteria and are willing to participate in this study, Mrs. HE, Mrs. ZI, and Mrs. FI. The study was conducted at the batik maker's house between 09.00-15.00.

\section{Instrument and Data Collection Techniques}

Data was collected using semistructured interview using interview guide developed by the researcher. Interviews were carried out while the batik makers carried out their activities as usual. We employed two strategies as a means for data validation: (1) triangulation of sources with mothers and business owners or batik group leaders, and (2) member examinations.

\section{Data analysis technique}

Data analysis in this study refers to the model of Miles and Huberman (1994) which consists of three activities, namely data reduction, data presentation, and conclusion making.

\section{Findings and Discussion}

Findings

Mrs. HE, has been involved in the world of batik making from an early age, and was influenced by the environment in which she lived, and also her mother and aunts. Although her mother did not teach batik directly, she often saw her mother and her neighbors making batik. HE's Aunt is the one who taught her to make batik. This pattern is similar with ZI and FI, they both claimed to be influenced by the family and their surrounding environment, in which the majority of them worked as batik makers.

Tradition and conformity are the basis of HE, ZI, and FI's motivation to make batik, even though they do not fully want it. HE does batik because her immediate environment also does batik, ZI also has similar reason coupled with economic conditions, while FI does batik because of traditions and economic conditions.

For vocational self-concept, HE was influenced by school and home environment. Actually, she is not that interested to become 
a batik maker, but still does batik because of the influence from the environment. Meanwhile, ZI was influenced by her mother who wanted her to be a batik maker. However, ZI herself has a belief that in the end she will make batik because she lives in Giriloyo. Furthermore, ZI's economic conditions forced him to earn money since she was in elementary school. ZI are only able to finish elementary school education, this in turn made her lack the confidence to do work other than making batik. As with FI, she never dreamed of being a batik maker. Instead, she wanted to migrate like her brothers. She claimed to make batik because it is the norm of the people as well as her peers around her to make batik. Furthermore, she made batik because she needed money as her parents did not always give her allowance due to economic conditions, and asked FI to make batik.

\section{Discussion}

The result indicates that all of the participants have not fulfilled the concern task of growth stage in their career development. HE did not think of the future when she began making batik, only because she often saw people around him making batik. Meanwhile, ZI only thought of meeting her needs at that time and to ease the burden on her parents, instead of concern for the future. FI made batik on the grounds of tradition and modeling her mother.

While HE's task to have career control has been fulfilled, ZI and FI has not fulfill it. Although HE's mother made batik, she did not compel her children to make batik and let them choose their own careers. HE made batike because she wanted to learn it at her aunt's place. Furthermore, even though HE claimed batik because of the environment, she has the power to decide and she chose to make batik. Meanwhile, ZI's mother asked her to make batik because of her family's economic condition. While FI made batik because she was urged to conform with the norms of her environment.

All participants fulfill the task of developing career conviction. This was supported by the fact that they have many examples as batik makers from their environment. This made them believe that they are also able to make batik. Furthermore, Giriloyo's children has been able to make batik as early as elementary school-age children who make batik after school.

All of the participants are able to fulfill competency task in career development. As was elaborated earlier, the participant's lives surrounded by batik makers, both in their family and their immediate surroundings. Holland (1958) added that there was a need for compatibility between personality and work environment. Compatibility between personality and work environment should be started to form during childhood. In this sense, Giriloyo's batik maker case are supported by this notion, as they have been shaped since their childhood to become batik makers. Family, especially mothers serves as trainer in batik making for the children, this in turn develop the child's competence in batik making. In summary, Giriloyo's batik makers do not fulfill all development tasks at the growth stage of career development.

At the next stage, exploration, both $\mathrm{HE}$ and FI did not develop vocational selfconcepts as batik makers, only ZI developed initial vocational self-concept as batik maker. However, all participants did not have a clear future orientation. At the previous stage, the participants are largely influenced by their parents and their environment, that renders them as the parties that lacked initiative. This in turn, inhibits their development in the next stage.

At this stage all participants do not underwent self-exploration and environmental exploration, so they have very little information on the job market and thus resulting in the absence of personal planning concerning their careers. HE did not do selfexploration because she saw herself as high school graduates, so there was no need to do self-exploration. She thinks those who understand their talents should go to vocational school, instead of high school. While ZI did not do self-exploration because she felt helpless due to her economic and educational background. While in FI's case, self-exploration does exists. However, it only 
appears after she enters the establishment stage. This implies that, in her journey to establish her career as a batik maker, she conducts no self-exploration. Prototypically, FI is yet in the exploration stage, but still in her establishment stage, this pattern was also seen in other participants whom should not be in the establishment stage yet due to the unfinished developmental tasks in the previous stage. This reveals a pattern of career development that is different from the established theory.

Regarding environmental exploration, all participants did not undertake environmental exploration. One of the reasons is the location of Giriloyo in the mountains and has difficulties to obtain cell signal and internet service providers. Housing and socioeconomic status are two of several factors that influence career exploration described by Taveira (2003). In this case, participants come from middle to lower socioeconomic status and live in rural areas.

Developmental tasks of career development in the exploration phase include crystallizing, specifying, and implementing. $\mathrm{HE}$ and FI did not fulfill the task of developing crystallizing careers because they did not want to be batik right from the start, so crystallizing could not be fulfilled. While ZI, from the beginning is willing to be a batik maker, so her crystallizing task can be fulfilled. Fulfillment of the developmental tasks in this stage is directly related to the participant's vocational self-concept.

The task of specifying development was not fulfilled in all participants. This is caused by the absence of environmental exploration, this made them does not have enough information to choose a career/job. However, the participants do not need specifying because they have been able to make batik since early years, which prototypically, they are yet to enter specifying stage. In addition, batik does not require certain formal education, instead it needs habituation.

The latest development task in the exploration stage is implementing. Only ZI has successfully fulfill the task. ZI was the only participants that prepares herself to work as a batik maker. This however, was due to ZI feels unable to do other work and saw herself as village girls who do not have much experience. HE and FI did not develop their self-concept and career preferences as batik maker, therefore they did not have anything to implement. Although, technically, all participants have the ability to make batik that has been trained since early on. So, even though HE and FI do not go through the implementing task, they still have expertise and competence equivalent to ZI. This condition limits their career choices to the dominant careers in their environment.

At the establishment stage, career identity begins to form. As discussed in the previous stage, HE and FI have no vocational interests or goals in the field of batik, while ZI has interests, talents, and vocational goals as batik maker, which realized in this stage. Although HE and FI do not want to work as batik maker, in the end they decided to work as batik maker around junior high through senior high school for HE, and around elementary to high school for FI. Their level of education also affects the reasons they make batik. ZI, who only has elementary school level education, does not have the desire and confidence to do other work. While HE and FI have the desire to work in other fields if the opportunity arises, because they see their wages obtained from their work as batik maker is not much. However, in the end, economic needs made them choose to work as batik maker.

Judging from Marcia's identity theory (1966), all participants were classified as having identity foreclosure status because they did not explore themselves and were immediately committed to batik. The influence of the environment and culture in this case is very apparent. Javanese culture encourages its' members to conform with the collective and upholds a sense of devotion to parents.

The first career development task in the establishment stage is stabilizing which is fulfilled for all participants. All three participants have the ability to make batik so that it no longer becomes a problem when they decide to make batik professionally. In addition, they live in areas where the majority 
are batik makers, this forces them to adapt whether consciously or unconsciously due to the overlap between living and work environments.

The second career development task is consolidating, which is successfully fulfilled by all participants. The three participants carried out sustainable productivity, even though they had stopped for a while due to other work. This brief stop happened due to the nature of the exploration stage that usually happened around this age. They returned to career exploration stage briefly even though they were already at the establishment stage. This career pattern becomes unique because the participants have been in the establishment stage since early without exploring themselves and the environment. While in the end they returned to making batik because they felt unable to do other work besides batik, the task of consolidating remains passed in a sub-optimal way.

The third career development task is advancing which refers to an attempt to rise to a higher position, in example, becoming a batik master artisan and opening hteir own shop. Batik making involves a long and varied stages. Starting with deciding and drawing the pattern, nyanthing or carving wax onto the cloth based on the pattern, coloring, and highlighting. These steps can be repeated for several times as needed. More colors on a batik cloth, means longer manufacturing process. Batik master artisan are able to carry out all of these processes from beginning to end. Even though a batik master artisan may delegate the tasks to his subordinates, they have mastered the key components for the crafts. In this sense, the highest level of batik maker is a batik master artisan and shop owner. The three participants did not wish to become batik master artisan and open their own shop because they are not confident with their batik making ability, has no managerial skills, and no capital to open a shop. All three participants said that batik making was only their side job, so there is no need to try to become a batik entrepreneur.

All participants entered the establishment stage prematurely. The establishment stage prototypically entered when they reached 25-44 years. The participants have been in that stage since ages 9-14 years. At that age range, they should not even have entered the exploration stage, let alone establishment age. This caused the participants to stop making batik and try other jobs before finally returning to make batik. In other words, they returned to exploration stage after entering the establishment stage. However, after returning to the exploration stage they are even more convinced to make batik and feel that batik making is the most suitable job for them.

Even though the participants decided to make batik again after trying to work in other fields, they felt dissatisfied with their batik making work claiming that they wanted other jobs if the opportunity arises. This causes them to oftenly feel unmotivated to make batik, due to the time consuming and meticulous work but does not pay much. On the other hand, they also feel quite happy with their job because they are able to carry out their main duties as housewives while still earning additional income. In addition, they feel proud to be part of Giriloyo batik maker, which has been famous since centuries ago. So that even though they are not satisfied with the wages, they are happy to take part in preserving long-standing traditions.

The demand for conformity among women in the village is quite high, so that making batik is an effort from the participants to be accepted in the community, theoretically this will limit their opportunity to selfactualize. But in reality, it does not bother them much, due to the lack of knowledge about themselves and the job market. In this case, their dissatisfaction is suppressed with their own aspirations. Even though they say they are not satisfied, they still want to make batik as long as they are able.

\section{Conclusion}

The participants did not fulfill the task of career development at the stage of growth, exploration, and establishment as a whole. The participants entered the establishment stage prematurely when compared to the prototypical age of 25-44 years, in this case 
they had begun to make batik around age of 9-14 years. While in theory 9-14-years-old put the participants within the growth stage.

At the growth stage, participants are heavily influenced by the family and the community to make batik, this caused them to become passive parties during the exploration stage. This results in their career choices being limited to the dominant careers in community. This led to dissatisfaction experienced in the establishment stage that makes them repeat the exploration phase that they haven't experienced yet. In the end, this process led them to make batik again and felt that making batik was a job that suited them and their skills.

Although the batik makers remain dissatisfied with the wages they receive, they feel proud to be a part of their community and want to continue batik as long as they are physically able. Furthermore, making batik is also participant's effort to conform with the environment they live in. So, in addition to meeting daily necessities, making batik was also their effort to preserve the cultural heritage of their ancestors.

\section{References}

Arulmani, G., Bakshi, A. J., Leong, F. T. L, \& Watts, A. G. (Eds). (2014). Handbook of career development: international perspectives. New York: Springer.

Brown, S. D. \& Lent R. W. (Eds). (2013). Career development and counseling: putting theory and research to work. New Jersey: John Wiley and Sons, Inc.

Gross-Spector, M. dan R. G. Cinamon. (2016). Assessing adults' career exploration: Development and validation of the vocational and maternal identity exploration scales. Journal of Career Development, 45 (1), 1933.

Guan, Y., Liu S., Guo, M. J., Li, M., Wu, M., Chen, S. X., Xu, S. L., \& Tian, Lin. (2018). Acculturation orientations and Chinese student sojourners' career adaptability: The roles of career exploration and cultural distance. Journal of Vocational Behavior, 104, 228-239.

Hartung, P. J., Porfeli, E. J., \& Vondrace, F. W. (2005). Child vocational development: A review and reconsideration. Journal of Vocational Behavior, 66, 385-419.

Marcia, J. (1966). Development and validation of ego-identity status. Journal of Personality and Social Psychology, 3 (5), 551558.

Miles, M. B. \& Huberman A. M. (1994) Qualitative data analysis 2nd Edition. Thousand Oaks: Sage Publications.

Super, D. E. (1980). A life-span, life-space approach to career development. Journal of Vocational Behavior, 16, 282-298.

Super, D. E. (1976). Career education and the meanings of work: Monograph on career education. Washington D. C.: Superintendent of Documents, U. S. Goverment Printing Office.

Super, D. E. \& Jordaan, J. P. Career development theory. (1973). British journal of guidance and counseling, 1(1), 316.

Super, D. E. (1972). Vocational development theory: Persons, positions, and processes. Dalam Whiteley, J. M. \& Resnikoff, A. (Eds.) Perspective on vocational development. Washington D. C.: American Personnel and Guidance Association.

Tiedeman, D. V., Roe, A., Super, D. E., \& Holland, J. (1972). Perspectives on vocational development. Washington D. C.: American Personnel and Guidance Association. 